\title{
USAGE AND MAGNETIZATION OF CLOUD COMPUTING IN HIGHER STUDIES - RAJASTHAN
}

\author{
Dr. Ranjan Upadhyaya, E-mail ranjanupadhyaya60@gmail.com \\ Professor \& Director, UBS- Mumbai- India \\ Dr M. Upadhyaya, E-mail makarandjaipur@gmail.com
}

\begin{abstract}
The Young India is a doorstep of another revolution of Cloud Computing Technology and the whole world adores the true colors of Indian Information revolution in the Global Recession. The India biggest and heavily densely populated country (1.6 Million according 20011 census surveys) India comprises of new age aspirants roughly $50 \%$ to $60 \%$ and out of these only $30 \%$ are Cloud Computing savvy. The uphill task lies ahead for the motherland is to train the new breads so that they can get their livelihoods and well connect them to the outer world. The inspiration of late Rajiv Gandhi's and Prof Yashpal dream is propagating into the reality but still more work is mingled up. The submergence of the Cloud Computing revolution is taking its all time cost and bring a lot more changes which was never expected or though off in our India. Cloud computing the ladder for success for the uncultivated breeds in our nation. The nation is marching ahead with the Sculpture of ubiquitous Cloud Computing in this liberalization, privatization and globalization era.
\end{abstract}

Keywords: Adore, Sculpture, Ubiquitous Transformation, Cloud Computing, Cost, Hallmark, Strategies, global recession.

\section{Introduction:}

The magic of the Cloud Computing has been inspired form many counties and form many concept. But few of the concepts are as follows.

* The term "Cloud Computing” in English, has come from Information Technology word of "Infomatiue' in French.

* Russian "Informatika” encompass the notion of 'Information Handling'.

In stricter sense Cloud Computing is the new science of collecting, storing, processing and transmitting information and connotes an ensemble of technologies and its proper management. They particularly cover the computer's capability to store, manage and process information (also know information processing) and communication technology, which is capable of transmitting information to distances. Basically Cloud Computing is application of tools and methods that support through which or by means of which information is transferred, recorded, edited, stored, manipulated, and disseminated.

According to the advisory council for Applied Research and Development of the Cabinet Office (Sept. 1980)1 of U. K. there are three key components of the cloud computing technology i.e. new ways to store information compactly and cheaply; new mechanism to manipulate, scan and search, such stores records; and new facilities for cheap and rapid transmission of information over long distance.

The objective of the Cloud Computing system in India, in a fundamental sense, is manpower planning aimed at equipping and synthesizing the user's right from their childhood the sense for bringing changes in our society and social life. It aims at creating intellectual awareness of our economics, social, political and cultural ethos. Indeed Cloud Computing is the basis of all planning, all development and all progress. As such, our programs of Cloud Computing should lie at the base of efforts to forge bonds of common citizenship, to harness energies of young aspirants and to develop natural and human resources of every part of the 
motherland. The social change involves the transformation of society from traditionalism to modernism, from backward, and from apathetic ignorance to active enlighten. In other words, social change brings about a new awakening in the masses with regard to their rights, duties and responsibilities towards society.

A significant contradiction in our Cloud Computing system is that while it should have been an instrument for bringing for about equality, in practices it has systematically sharpened and deepened inequalities. It has not been appreciated that for bringing about social change and social justice, the major thrust should be on primary Cloud Computing because it is that the content and formalism of Cloud Computing scares away the children of the poor and the backward classes. It is that wrong ideas and attitude towards national and social issues are inculcated. Currently, about 49 percent of the children drop out in the primary school stage.

More vigorous efforts are required to spread Cloud computing in rural areas so as to change the total environment and thinking in villages. The technology is one of the highest ingredients, which makes the accessibility of acceptance

Table No - I X -Plan (Five - Year Plan):

\begin{tabular}{|l||l|l||}
\hline \hline $\begin{array}{l}\text { YEA } \\
\text { R }\end{array}$ & Plan & Non-Plan \\
\hline $\begin{array}{l}2002- \\
03\end{array}$ & 559.76 & 1100.00 \\
\hline $\begin{array}{l}2003- \\
04\end{array}$ & 516.75 & 1132.30 \\
\hline $\begin{array}{l}2004- \\
05\end{array}$ & 719.75 & 1182.85 \\
\hline $\begin{array}{l}2005- \\
06\end{array}$ & 374.41 & 609.17 \\
& $\begin{array}{l}\text { (upto } \\
31.8 .05)\end{array}$ & $\begin{array}{l}\text { (upto } \\
31.8 .05)\end{array}$ \\
\hline
\end{tabular}

(Sources: Ministry of Cloud Computing, GOI, New Delhi, 2008) with understanding of teaching \& learning. There is very high significance of technology in the Cloud Computing in the countries like India where inequalities in Cloud Computing are high and social unawareness about the Cloud Computing also high. The use of technology can bolster the new waves. It can enhance and enrich the innovative skill of the common people. The technology is non-stop advancement of teaching and learning.

There have so far been mainly two comprehensive statements of the National Policy on Cloud Computing, viz. from Information Technology, those of 1968 and 1986. The former contained decisions of the Central Government on the recommendations of the National Commission on Cloud Computing Vis Information Technology in, 1964-66. The latter was a result of the renewed priority assigned to Cloud Computing by the government of the Late Shri Rajiv Gandhi, who was Prime Minister during 1984-89. Thus, in all, the following three comprehensive national policy statements exist on Cloud computing vs. Information Technology:

*ational Policy on Information
Technology, 1968
*ational Policy on Information
Technology, 1986
* National Policy on Information
Technology, 1986, as modified in 1992

\section{National Cloud Computing Infrastructure:}

A reliable network infrastructure is a prerequisite for the development of web-based Cloud Computing. This has to be affordable to the Cloud Computing in our motherland and the individuals and available in a variety of forms such as - leased lines, ISDN, Internet, ADSL, ATM and with adequate width. Some of the initiatives taken in this regard are:

* Internet access nodes are being provided in all Secondary Switching Areas by December 2000. This will be based on a fiber optic cable connectivity, which will link the nodes with a higher speed network. It will provide high speed and motherland wide interconnect points to the ISPs. National 
internet Backbone-I is being set up, which will help the remote areas of this motherland also to have access to the high quality Internet services.

* A National Technology Mission, 'Project Sankhya Vahini (PSV)' has been planned for establishing a very high bandwidth All India National Data Network through a joint venture company known as Sankhya Vahni India Limited (SVIL). The company will establish and operate nationwide high bandwidth data network to provide high speed data access to Cloud Computing in our motherland, private and public corporations, service providers, organizations and individuals, etc. for learning, training, research and other multimedia activities. SV Network can be used very effectively for distance learning, Teleconferencing, setting up universal digital libraries and hazard \& disaster management. This network will be primarily a data network forming the National Backbone at speeds of 40 Gbps -60 Gbps.

\section{Objective of the Research:}

\section{* The objective is to evaluate the extent of cloud computing technology in use and its impacts on new age aspirants in Global Recession \\ Research Design:}

Data's:

The researcher has tried his best to collect few data from the primary sources also through closed questionnaires. The secondary data would be collected from the published annual reports, company's policy letters and other available published and non-published sources.

\section{Processing of Information Collected:}

The collected data were arranged in a required manner mostly from of schedules, tables and statements collected by secondary source of Information.

\section{RELEVANCE OF RESEARCH:}

The relevance and important of the research work is highly demanding and challenge in present scenario when Indian economy is at a boom stage and everyone want to go for the short gain. Cloud Computing are the right ladder for facilitators to these 330 millions Young aspirants through maximum knowledge. Cloud Computing is not only means of economic power but also all round development of the 330 millions young aspirants of our motherland. If the motherland has to come in fore front of the world superpower then only development of the citizens in India and for India and by India is possible through maximum utilization of the Cloud Computing.

\section{Outcomes:}

The researchers made an attempt to examine the respondent resources in different centre of excellence located in Rajasthan. Following seven important segments of Cloud Computing practices as well an aggregate quality of Cloud Computing practices in the different centre of excellence were examined motherland among different age group of different caste etc. The detailed analyses of the above segments are as follows: 
Graph No -1

Cloud Computing Users among the uncultivated Young users in Global Recession

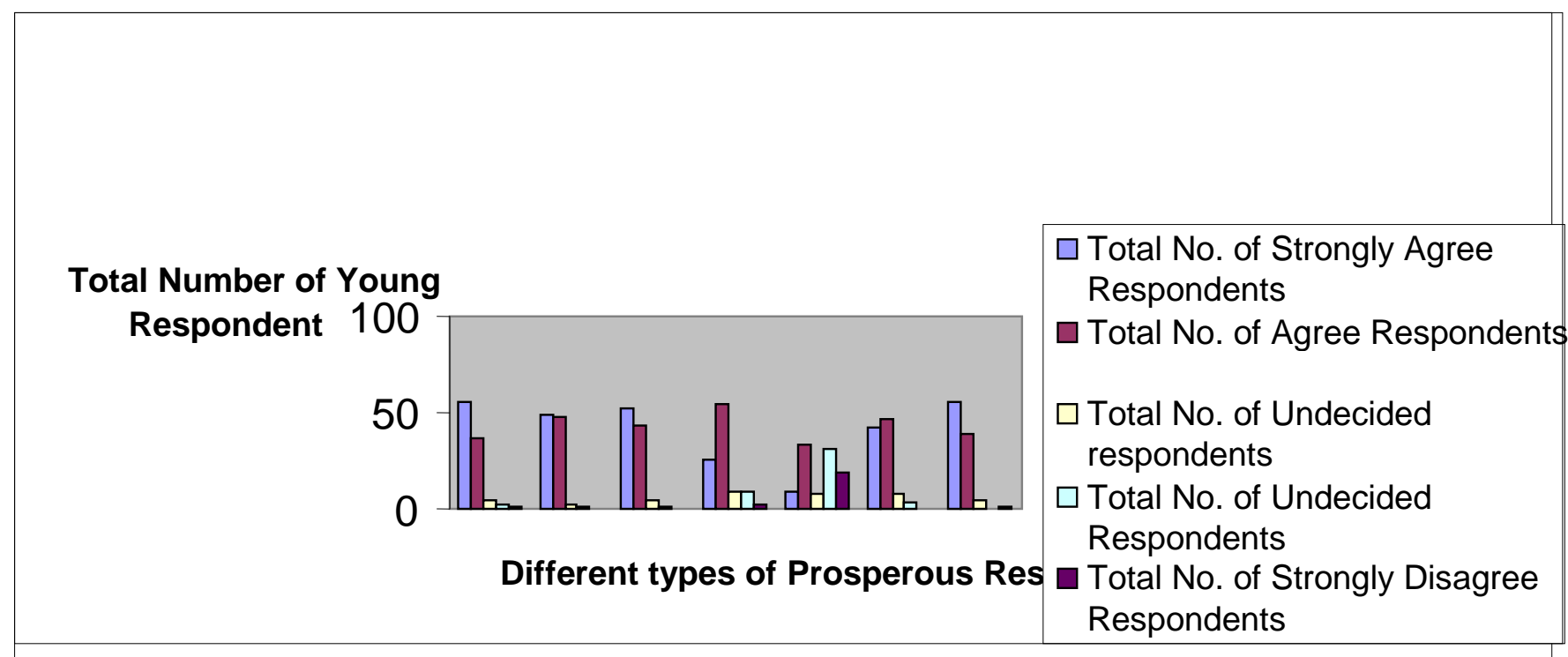

Table No -II - Percentage of the Cloud Computing users in Global Recession

\begin{tabular}{|c|c|c|c|c|c|}
\hline Que. No. & T. No of S. A. Ans. & T. No of A. Ans. & T. No of U. Ans. & T. No of D. Ans. & T. No of S. D. Ans. \\
\hline 1 & $56 \%$ & $37 \%$ & $4 \%$ & $2 \%$ & $1 \%$ \\
\hline 2 & $49 \%$ & $48 \%$ & $2 \%$ & $1 \%$ & NIL \\
\hline 3 & $52 \%$ & $43 \%$ & $5 \%$ & $1 \%$ & NIL \\
\hline 4 & $26 \%$ & $54 \%$ & $9 \%$ & $9 \%$ & $2 \%$ \\
\hline 5 & $9 \%$ & $33 \%$ & $8 \%$ & $31 \%$ & $19 \%$ \\
\hline 6 & $42 \%$ & $47 \%$ & $8 \%$ & $3 \%$ & NIL \\
\hline 7 & $56 \%$ & $39 \%$ & $4 \%$ & NIL & $1 \%$ \\
\hline Mean & 41.428 & 43 & 5.7142857 & 6.714285 & 3.2857143 \\
\hline
\end{tabular}


Table No -III - Few New Models in Integrating Cloud Computing Among The Uncultivated Young Aspirants:

\section{Weighting Contextual Targets in Higher Education}

\begin{tabular}{l|l} 
Costs: & Access:
\end{tabular}

- high economics of scale

- low unit production

- low initial capital investment provision

Technical:

- $\quad$ high student affordability

- low student skill needed

- low earning central access

- high production capacity

- high sustainability

- high package integration

Pedagogical:

- high delivery speed

- low internet bandwidth occupation

- high platform independence

- high "reach/footprint"

- high synergy (compatibility)

- high asynchronous to synchronous

- high students skills benefit

- high didactical control

- high two-way communication

- high collaboration

- high staff access

- low labor investment

- low staff skill needed

(Source: Report Published in Cloud Computing chapter of UNESCO, 2008, P.47).

At the end, result may be drawn to satisfy the objectives of the given research. So thus we find that a for maximum use of Cloud Computing its varying role in both rural and urban India can revolutionize the whole population firstly by the providing the cheap, easily, quickly, flexible Information Technologies and it can be a ladders/tentacles in whole life of uncultivated young aspirants of motherland for daily earning too. To attain 9\% growth rate and to utilize the $18 \%$ of the Cloud Computing budget out of the total budget it is found out that only online good Cloud Computing through use of the latest blend of technology can cater the needs of the uncultivated young aspirant's dreams.

\section{Talks of Today:}
$\checkmark$ Young India has to march ahead to bring new breed of Information savvy talent in our country.
$\checkmark \quad$ Young India is the young blood and source of revenue neutralization in our country.
$\checkmark$ Young India is the dream of tomorrow and can grow, survival and live with more Cloud Computing cult.

\section{Concluding Observations:}

The study suggest the various parameters and hard fact that without cultivating the young talent it will be lose for the nation to usage the technology which is the path of the success and livelihood for the unemployed youth in our nation. The study revivals many true suggestions with respect to the area selected in this study, which has been highlighted. 


\section{Suggestions:}

i) Variable quality of Cloud Computing in our motherland.

ii) The system of affiliation of excellence of Cloud Computing platforms followed by the most center of excellence, which centralizes, decisions and discourages accountability.

iii) Inflexibility in academic structure that inhibits innovation and promotes mediocrity.

iv) Inadequate financial supports for Cloud Computing form the government and society in general.

v) More funds to sustain the fuel of usage of Cloud Computing in the country.

\section{"Quality education produces good learning outcomes - and the initial training and preparation of Cloud Computing contribute to this aim"}

(Source: Report Published in Cloud Computing chapter of UNESCO, 2008, P.49).

\section{Bibliography}

\section{Different Books:}

* Mahajan Preeti, "Technological Impact on Cloud Computing: Prospects for India" Centre of excellence News, New Delhi, 2004.

* Singh B.P., Y. Upadhyaya, Cloud Computing in the New Millennium, Centre of excellence News, New Delhi, 2002.

* Ghosh D.K., Higher Cloud Computing in the 21st Century Meeting the Challenge,
Centre of excellence News, New Delhi, 1996

* Mishra Rajendra, "Evolutionary and

Revolutionary: Information and

Communication Technology" University

News, Vol 46, N0-1, January 2008

\section{Government of India Reports:}

* UNDP, HQ, New York, USA, Report -2001

* Acharya Ramamurti, chairman of the committee constituted by central government during the regime of Late Shri Rajiv Gandhi to look after the quality of Cloud Computing in higher Cloud Computing in our motherland in India, 1986, 1992.

* Ministry of Cloud Computing, GOI, New Delhi, 2005, (www.nic.ac)

\section{Different Web Sites:}
* http://www.aicte.ernet.in
* http://www.imi.edu
* www.aiuweb.org
* http://www.mcu.ac.in/
* http://www.glencoe.com/sec/teachingto day/downloads/pdf/Considerations Util izing_Tech.pdf
- http://www.wiche.edu/telecom/projects/ balancing/principles.htm

\section{Different Journals \& Magazines}

$>$ Educom Review, 1999

> Cloud Computing Review, Basbson University Press, Australia, 2005 